\title{
Towards eLearning 2.0 University
}

Citation for published version (APA):

Berlanga Flores, A. J., García, F., \& Sloep, P. (2010). Towards eLearning 2.0 University. Interactive LearnIng Environments, 18(3), 199-201. https://doi.org/10.1080/10494820.2010.500498

DOI:

$10.1080 / 10494820.2010 .500498$

Document status and date:

Published: 01/09/2010

Document Version:

Peer reviewed version

Please check the document version of this publication:

- A submitted manuscript is the version of the article upon submission and before peer-review. There can be important differences between the submitted version and the official published version of record. People interested in the research are advised to contact the author for the final version of the publication, or visit the DOI to the publisher's website.

- The final author version and the galley proof are versions of the publication after peer review.

- The final published version features the final layout of the paper including the volume, issue and page numbers.

Link to publication

\section{General rights}

Copyright and moral rights for the publications made accessible in the public portal are retained by the authors and/or other copyright owners and it is a condition of accessing publications that users recognise and abide by the legal requirements associated with these rights.

- Users may download and print one copy of any publication from the public portal for the purpose of private study or research.

- You may not further distribute the material or use it for any profit-making activity or commercial gain

- You may freely distribute the URL identifying the publication in the public portal.

If the publication is distributed under the terms of Article 25fa of the Dutch Copyright Act, indicated by the "Taverne" license above, please follow below link for the End User Agreement:

https://www.ou.nl/taverne-agreement

Take down policy

If you believe that this document breaches copyright please contact us at:

pure-support@ou.nl

providing details and we will investigate your claim.

Downloaded from https://research.ou.nl/ on date: 26 Apr. 2023 


\section{Towards eLearning 2.0 University (Guest Editorial) \\ Adriana J. Berlanga ${ }^{a^{*}}$, Francisco García Peñalvo ${ }^{b}$ and Peter B. Sloep ${ }^{a}$ \\ ${ }^{a}$ Centre for Learning Sciences and Technologies (CELSTEC), Open University of The \\ Netherlands; ${ }^{b}$ Computer Science Department, University of Salamanca, Spain \\ *Corresponding author. Email: adriana.berlanga@ou.nl}

\section{Introduction}

This special issue is dedicated to the question of how universities should integrate Web 2.0 technologies and tools into educational and institutional practices. This question is driven by the assumption that eLearning 2.0, as this integration is called, will foster the idea of placing the learner in the centre of a more social, personal and flexible learning process. This requires not only a technological shift but also, and more importantly, a conceptual change in which all stakeholders conceive learning as a social activity, which occurs in interaction with others. Before introducing more in depth the contributions of this special issue, it is worth to point out the most relevant insights on this topic.

Importantly, rather than as a technological, instructional design, or institutional challenge, the inclusion of Web 2.0 tools into university practice is perceived as a challenge for learners. They need to shift away from traditional learning strategies and individual and passive approaches towards working collaboratively in social, situated contexts (Karasavvidis, Lim et al.). Students actually are not familiar with the activities required to sustain authentic collaboration (Huang \& Nakazawa). Support should be provided to develop their competences on this respect.

It is also relevant to explore the potential of Web 2.0 tools for developing higher order skills, such as reflection on action, and critical thinking. These tools do have the potential to foster these skills (Wopereis et al., Mendenhall \& Johnson). To make the most of them, nevertheless, learners require support on how to use these tools for meaningful reflection 
(Wopereis et al.). At the same time, tutors and instructional designers should bear in mind that the quality of the instruction will improve if Web 2.0 tools are incorporated in the learning process, as is evidenced by grounded instructional design theories and models (Mendenhall \& Johnson).

eLearning 2.0 also means a shift from the traditional university model of providing education, towards a more flexible and open learning approach. Personal Learning Environments give learners control of their learning process by providing a single access point to services, tools, people and resources. Learner control in these environments implies that learners will increasingly take responsibility over crucial instructional functions. It is evident that universities can play an important role in developing students' competences to control their learning projects and environments (Väljataga \& Laanpere). It is also evident that universities should not be excluded from Personal Learning Environment approaches, quite the opposite, they can greatly benefit from Web 2.0 tools and services (Casquero et al.).

\section{Contributions}

In the opening article of this special issue, Lim, So and Tan argue that technological, social and epistemological dimensions should be considered to exploit the opportunities that Web 2.0 approaches offer. After having observed that students show little depth-collaboration while having been asked to work in wiki, the authors conclude that changes on the sociotechno-spatial relations and learning practices are needed.

Likewise, while exploring the barriers to a successful implementation of wikis, Karasavvidis concludes that current learning practices are incompatible with wiki requirements and, therefore, that students should be introduced to new learning practices, and have support on procedural and epistemological issues.

Huang and Nakazawa present an exploratory study that aimed to investigate how students interact using wikis as a learning tool. Their study included the activities students participate 
in, how students perceived the level of interaction with peers and tutors, and if there was a difference between peer-to-peer and student-to-tutor interactions. Their findings suggest that interaction among peers is higher than interaction between students and tutors. They also show that students need support to sustain wiki activities such as writing, reviewing, revising, as they are not accustomed to the dynamic collaborations that are so specific to wikis.

Wopereis, Sloep and Poortman present a study of the use of weblogs as a means to promote students teacher's reflective practice. They conclude that weblogs are suitable for structured reflective writing and feedback. In their study they also found students learning practices at odds with Web 2.0 approaches. Students' reflections were superficial, the average number of feedback was not as high as expected, and large discussions were scarce. Students like ample comments on their postings but, paradoxically, they were of the opinion that weblog access should be limited to members of their student group.

Mendenhall and Johnson propose a combination of Web 2.0 tools and grounded instructional design theories and models. The authors explore the use of a Web 2.0 tool, HyLighter, which employs a social annotation instructional strategy. They report three different studies, which combined instructional activities using HyLighter for peer-critique, and critical analysis, comprehension and metacognition. Their findings include student perceptions on the benefits, weaknesses, and usability of the HyLighter tool. It turns out that on average, students exhibited slightly better cognitive skills after exposure to the learning method. Moreover, students showed more critical thinking skills than comprehension skills, but they did not show change in metacognition.

Väljataga and Laanpere present a theoretical framework for Personal Learning Environments, which integrates instructional functions of learner control. They explain their understanding of the learner control over instructional functions in relation to instructional design and Personal Learning Environments. Authors exemplify the applicability of their 
theoretical framework in an intervention implemented in an eLearning course. They notice that, apparently, students find it difficult to create learning contracts and to choose tools and services for their learning environment. Nonetheless, students appreciated the increased learner control and the use of technology for managing learning.

Casquero, Portillo, Ovelar, Benito and Romo propose an approach that combines personal and institutional spheres to support eLearning 2.0 within a higher education institution. They propose an architecture, based on widgets, which allows one to merge Web 2.0 tools, services, personal social networks, and institutional content management systems in what they call (institutionally) Personal Learning Environment. Their PLE approach puts learners in control of their learning evidences by integrating existing Web 2.0 repositories in the routine of content generation; this also means including the social networks that learners maintain within and outside the institution. These authors present a prototype that has been developed as a proof of concept, and report its technical specifications.

\section{Acknowledgements}

This special issue would not have been possible without the generous support of reviewers.

Our sincere thanks go to:

Terry Anderson

Francis Brouns

Carlos Castaño

Peter Dolog

Jon Dron

David Griffiths

Begoña Gros

Marco Kalz

Ralf Klamma

Milos Kravcik

Katrina Maxwell

Paola Monachesi

Symeon Retalis

María José Rodríg

German Ruipérez

Sandra Schaffert

Judith Schoonenboom
Athabasca University, Canada

Open University of The Netherlands, The Netherlands

University of the Basque Country, Spain

Aalborg University, Denmark

Athabasca University, Canada

University of Bolton, UK

Open University of Catalonia (UOC), Spain

Open University of The Netherlands, The Netherlands

RWTH Aachen, Germany

Open University of The Netherlands, The Netherlands

INSEAD, France

Utrecht University, The Netherlands

University of Piraeus, Greece

University of Salamanca, Spain

Spanish National Open University (UNED), Spain

Salzburg Research Forschungsgesellschaft m.b.H, Austria

University of Amsterdam, The Netherlands 
Slavi Stoyanov

Steven Verjans

Riina Vuorikari

Scott Wilson

Iwan Wopereis
Open University of The Netherlands, The Netherlands Open University of The Netherlands, The Netherlands European Schoolnet, Belgium

University of Bolton, UK

Open University of The Netherlands, The Netherlands

We would like to thank Steve Wheeler and Joseph Psotka, editors of the Interactive Learning

Environments Journal, for their warm acceptance of this special issue, and the support during the preparation process. Last but not least we are grateful to Mieke Haemers for her proofreading work.

This work has been partly sponsored by the TENCompetence Integrated Project, funded by the European Commission. Contract 027087 (http://www.tencompetence.org), by the MIH (Multicultural Interdisciplinary Handbook) project, funded by the European Commission's LifeLong Learning Program, and by the Department of Education of Junta de Castilla y León (Spain) through the project GR47.

We hope you enjoy the special issue. 